\title{
Characterization of a Low Pathogenic Avian Influenza Virus (H6N1) Isolated from Turkeys
}

\author{
I. Shkoda, ${ }^{1}$ E. Lapin, ${ }^{1}$ E. Rosenbluth,, ${ }^{1}$ S. Perk, ${ }^{1}$ Z. Geva, ${ }^{2}$ A. Inbar, ${ }^{3}$ and I. Davidson ${ }^{1}$ \\ ${ }^{1}$ Division of Avian Diseases, Kimron Veterinary Institute, P.O. Box 12, Bet Dagan 50250, Israel \\ ${ }^{2}$ Yeffe-Hod, Turkey Breeding Farms and Hatcheries, Kvutzat Yavne, P.O Evtach, 79233, Israel \\ ${ }^{3}$ Israel Veterinary Services, Southern Diagnostic Laboratory for Poultry, Beer Tuvia, Israel
}

Correspondence should be addressed to I. Davidson, davidsoni@int.gov.il

Received 10 August 2010; Revised 30 November 2010; Accepted 13 December 2010

Academic Editor: Mikhail Matrosovich

Copyright () 2011 I. Shkoda et al. This is an open access article distributed under the Creative Commons Attribution License, which permits unrestricted use, distribution, and reproduction in any medium, provided the original work is properly cited.

\begin{abstract}
An avian influenza virus (AIV), A/turkey/Israel/09 subtype H6N1, was isolated from turkey poults exhibiting typical pathology associated with AIV infection. The virus was characterized by RT-PCR using AIV subtype-specific primers and by the haemagglutination inhibition test using AIV subtype-specific antisera. The virus has an intravenous pathogenicity index of 0 and possessed a nucleotide sequence at the cleavage site of the hemagglutinin gene, PQIETR*GLF, associated with avian influenza viruses of low pathogenicity. Unlike the two previous $\mathrm{H} 6 \mathrm{~N} 2$ isolates originating from domestic ducks and mallard, the A/turkey/Israel/09 (H6N1) was isolated from turkeys. The gene sequences of the A/turkey/Israel/09 (H6N1) virus show divergence from the former Israeli H6 isolates.
\end{abstract}

\section{Introduction}

The influenza viruses include three genera, $\mathrm{A}, \mathrm{B}$, and $\mathrm{C}$ within the family Orthomyxoviridae. Avian influenza viruses (AIVs), all of which are contained in the genus influenza virus $\mathrm{A}$, are an economically important cause of disease in fowl and occasionally affect humans, pigs, and horses $[1,2]$.

Each genus of the virus is further subdivided into serotypes based on the surface proteins, consisting of 16 different hemagglutinin $(\mathrm{H})$ and 9 neuraminidase $(\mathrm{N})$ subtypes. While only a limited number of $\mathrm{H}$ and $\mathrm{N}$ subtypes are circulating in humans and other mammalian species, all the $\mathrm{H}$ and $\mathrm{N}$ subtypes are found in avian species $[3,4]$. The genome of influenza A viruses consists of 8 unique segments of single-stranded negative sense RNA. The viral RNA segments encode 10 recognized gene products, $\mathrm{PB} 1, \mathrm{~PB} 2$, and PA polymerases, $\mathrm{H}, \mathrm{NP}, \mathrm{N}, \mathrm{M} 1, \mathrm{M} 2$, NS1, and NS2 proteins [5].

The H6 subtype is one of the most commonly recognized subtypes in domestic ducks in southern China $[6,7]$ and in migratory birds in North America and in Europe [8-10]. H6 viruses have caused several outbreaks in commercial poultry worldwide that resulted in decreased egg production and increased mortality [11-13]. During the Hong Kong H5N1 "bird flu" incident in 1997, an H6N1 avian influenza virus, teal/Hong Kong/W312/97 (W312), was isolated from birds in a live poultry market [14]. Genetic characterization of this virus revealed that except for the $\mathrm{H}$ gene, the remaining 7-gene segments were closely related to those of highly pathogenic avian influenza H5N1 viruses (HPAIVs) found in both poultry and humans [14].

The present study reports on the outbreak of avian influenza (AI) caused by an H6N1 subtype of AIV isolated during January 2009 in Kibbutz Gvulot, in the southern part of Israel. The present isolate, A/turkey/Israel/09 (H6N1), is the third H6 AIV obtained in Israel since the year 2000. Therefore, circulation of these viruses was concurrent with that of the highly prevalent H9N2 AIV in Israel $[15,16]$. While the former H6 AIV isolates, A/duck/Israel/289/01 (H6N2) and A/mallard/Israel/320/01 (H6N2), were isolated from water birds, the present isolate was obtained from domestic turkey poults. 


\section{Materials and Methods}

2.1. Description of the Flock of Origin. Six week-old turkey poults in one of six poultry houses (no. 2) located in one farm, Kibbutz Gvulot, exhibited an increased daily mortality of approximately $1 \%$ over a two-day period. The clinical signs were swollen infraorbital sinuses, nasal discharge, respiratory rales, rattles, and lethargy. Pneumonia, pericarditis, air sacculitis and tracheal discharge were observed on postmortem examination. Birds in the affected poultry house had developed AIV antibodies, as detected by ELISA and AIV H6 haemagglutination inhibition (HI) tests. The ELISA test was performed with the FlockChek Avian Influenza Antibody Test Kit (IDEXX, USA) according to the manufacturer's instructions, and the HI test employed a panel of reference antisera to $\mathrm{H} 5, \mathrm{H} 6, \mathrm{H} 7$, and $\mathrm{H} 9$. Blood samples were tested for antibodies by the HI test using 4 (HA) units of the H6 subtype antigen [17]. Turkey poults from the six houses were distributed to 4 secondary farms, Mishmeret, Ramon, Ein Zurim, and Evron.

2.2. Virus Detection. Tracheal and cloacal swabs of clinicallyaffected turkeys were assayed for the presence of AIV by PCR and virus isolation in 11-day-old embryonated eggs [17]. The presence of AIV was initially detected in the allantoic fluids (AF) of dead eggs after 2-3 days of incubation, by the hemagglutination (HA) assay [17]. Testing of HA-positive $\mathrm{AF}$ was performed by reverse transcriptase polymerase chain reaction (RT-PCR). In parallel, RT-PCR was performed on RNA extracted directly from tracheal and cloacal swabs.

2.3. Molecular Characterization of AIV. Viral RNA was extracted directly from the tracheal and cloacal swabs and from AF using the QIAamp Viral RNA Mini Kit (Qiagen, Valencia, CA) according to the manufacturer's instructions. The purified RNA was then tested by RT-PCR.

Firstly, AIV was detected using a primer pair specific for the $\mathrm{M}$ gene of influenza A virus, Mf (5' -TTCTAACCGAGGTYRAAACGT- $\left.3^{\prime}\right)$ and $\mathrm{Mr}$ (5'-CTGGGCACGGTGAGCGT$3^{\prime}$ ) to amplify a 200 bp product (Panshin A., Kimron Veterinary Institute, Bet Dagan, Israel, unpublished). RT-PCR was performed using a One Step RT-PCR kit, (QIAGEN Ltd.). A $25 \mu \mathrm{l}$ mixture containing $5 \mu \mathrm{l}$ of buffer, $1 \mu \mathrm{l}$ of dNTP mix, $1 \mu \mathrm{l}$ of each primer, $1 \mu \mathrm{l}$ of One Step Enzyme mix, $13 \mu \mathrm{l}$ nucleasefree water, and $3 \mu \mathrm{l}$ RNA template was used in the assay as follows: $30 \mathrm{~min}$ at $50^{\circ} \mathrm{C}, 10 \mathrm{~min}$ at $95^{\circ} \mathrm{C}, 30$ cycles at $94^{\circ} \mathrm{C}$ for $30 \mathrm{sec}$, then $30 \mathrm{sec}$ at $54^{\circ} \mathrm{C}, 30 \mathrm{sec}$ at $72^{\circ} \mathrm{C}, 5 \mathrm{~min}$ at $72^{\circ} \mathrm{C}$, and $15 \mathrm{~min}$ at $4^{\circ} \mathrm{C}$ using the DNA Engine thermal cycler (Bio Rad, Waltham, MA, USA). The RT-PCR product was separated by electrophoresis in $2 \%$ agarose gel.

Secondly, molecular subtyping was performed with a set of specific primers for genes of $\mathrm{H}$ subtypes $\mathrm{H} 1-\mathrm{H} 4$, H6, H9, and H10 [18] and H5, H7 [19], and N subtypes N1 [20] N2, N3, N7, N9 (Panshin A., Kimron Veterinary Institute, Bet Dagan, Israel, unpublished). The primers used to amplify a $623 \mathrm{bp}$ segment of the N2 gene were N2f $\left(5^{\prime}\right.$ YTGYACAGTRGTAATGACBGATGGR-3') and N2r (5' CRATRCTRYTTGADGTCCACCABAC- $3^{\prime}$ ); The primers to used to to amplify a $470 \mathrm{bp}$ product of the $\mathrm{N} 3$ gene were N3f (5' -AAYAGRCCWTGGRTGAGRAT- $\left.{ }^{\prime}\right)$ and N3r ( $5^{\prime}$ CCCGATCCAGGTTCATTGT- $\left.3^{\prime}\right)$. The primers used to amplify a $509 \mathrm{bp}$ segment of the N7 gene were N7f $\left(5^{\prime}\right.$ TTGGRTGGTCRAGYACAAGCTGCC- $\left.3^{\prime}\right)$ and N7r (5' ACCAGGRCTYCCAGTDATWGGATTG-3'), the primers used to amplify a 520 bp segment of N9 gene were N9f ( $5^{\prime}$ CAACCAATGCAAGCCAAACAATA-3') and N9r (5' CGGGCCCATGTGTTGATTTC- $3^{\prime}$ ). The amplification conditions for $\mathrm{H}$ and $\mathrm{N}$ genes were similar to those of the $\mathrm{M}$ gene.

2.4. Sequence Analysis. The PCR products were purified with the MEGAquick-spin PCR \& Agarose Gel Extraction System (iNtRON Biotechnology, Inc, Gyeonggi-do, Korea) according to the manufacturer's instructions. Sequencing reactions were performed by the Weizmann Institute of Science, Rehovot, Israel, using a 3700 DNA Analyzer (PerkinElmer, Applied Biosystems, Foster City, CA., U.S.A.) and analysed by capillary electrophoresis. The BioEdit Package, Version 7.3, and DNASTAR system software were used for sequence analysis and alignment.

2.5. Phylogenetic Analysis. Nucleotide sequences of all gene segments and available sequence data from GenBank were used to generate phylogenetic trees. The phylogenetic analysis was performed with the MegAlign programme of the DNASTAR system Software.

2.6. IVPI Test. The intravenous pathogenicity index (IVPI) of AIV isolates was determined as described in the OIE Manual of Standards for Diagnostic Tests and Vaccines [21]. The test employs a standard volume of virus which is inoculated intravenously into SPF chickens. The IVPI test yields an index of virulence valued from 0 to 3 , which is calculated according to illness severity and the viability period following inoculation [21].

\section{Results and Discussion}

3.1. Virus Transmission. The Mishmeret farm received poults from the original poultry houses nos. 1 and 4 and developed a low level of HI antibodies (geometric mean titer (GMT) = 1.8 ); the Evron farm received poults from the original poultry houses nos. 5, and 6 and did not develop HI antibodies (GMT $=0)$; the Ramon farm received poults from the original poultry houses nos. 1, 4, 5 and 6, and did not develop HI antibodies (GMT $=0$ ); the Ein Zurim farm received poults from the original poultry house no. 2 , that was infected with the A/turkey/Israel/09 (H6N1) isolate, and from house no. 3. As a result, birds on the Ein Zurim farm developed $\mathrm{HI}$ antibodies to $\mathrm{H} 6$ and showed clinical signs $(\mathrm{GMT}=6.3)$.

3.2. Virus Identification and Virulence Determination. To identify the AIV $\mathrm{H}$ and $\mathrm{N}$ gene, specificity amplifications and $\mathrm{HI}$ assays were performed indicating the H6N1 subtype of the isolate. The virus was isolated and characterized by classical methods (OIE) and genome was detected by 


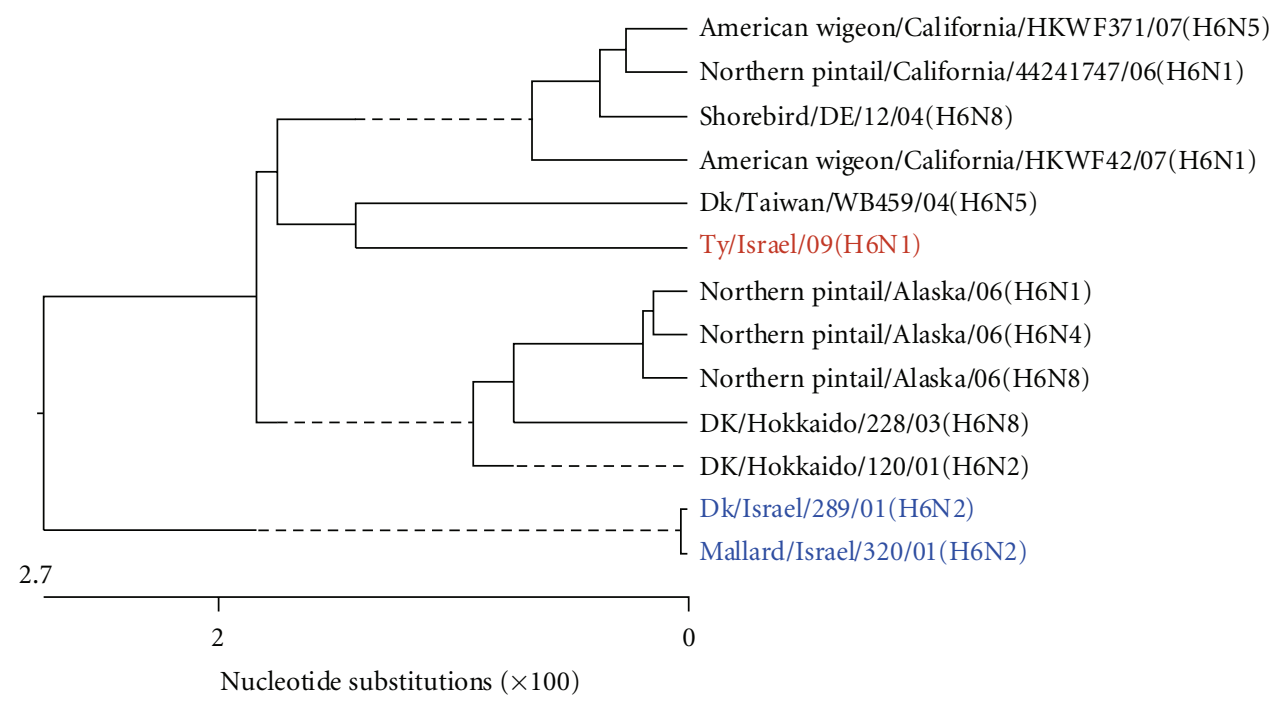

Figure 1: Phylogenetic tree of the $\mathrm{H}$ gene of $\mathrm{H} 6$ subtype. Here and in the Figures 3-8, the analysis was based on corresponding complete genes.

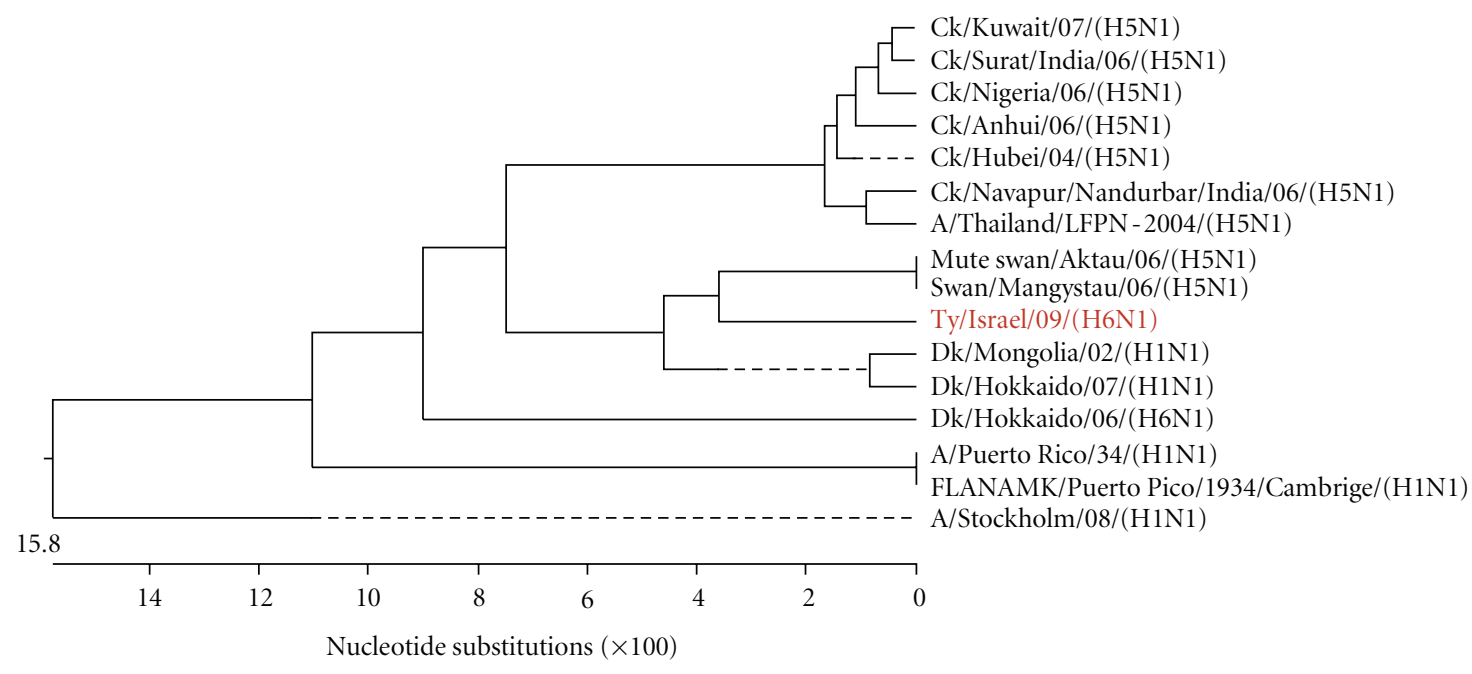

Figure 2: Phylogenetic tree of the N gene of N1 subtype. Analysis was based on nucleotides 204 to 1149 of the N gene.

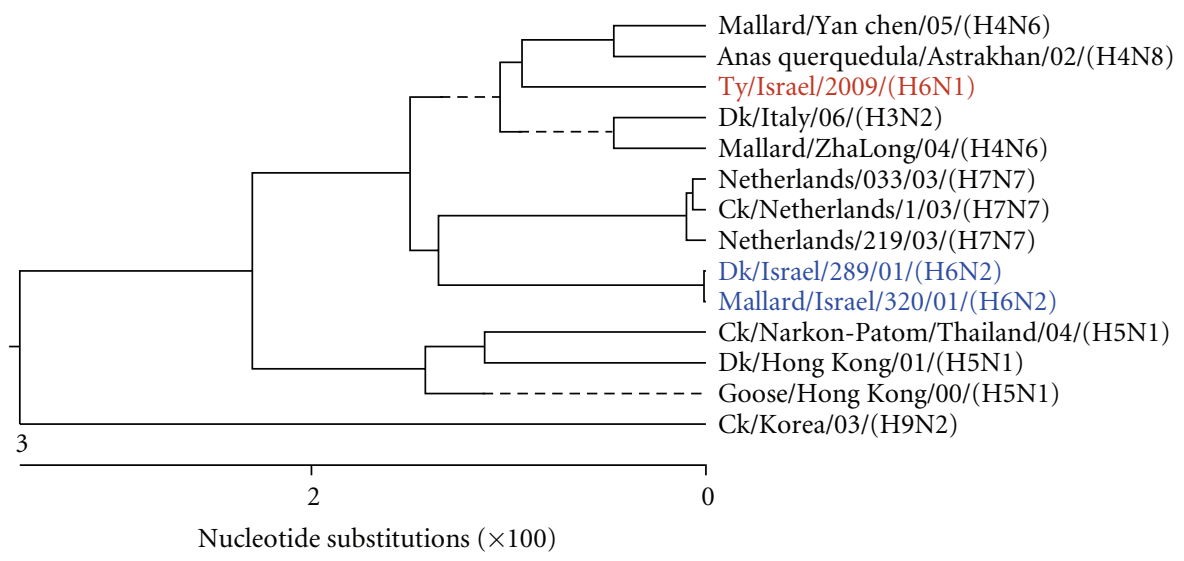

FIgUre 3: Phylogenetic tree of the NS gene. 


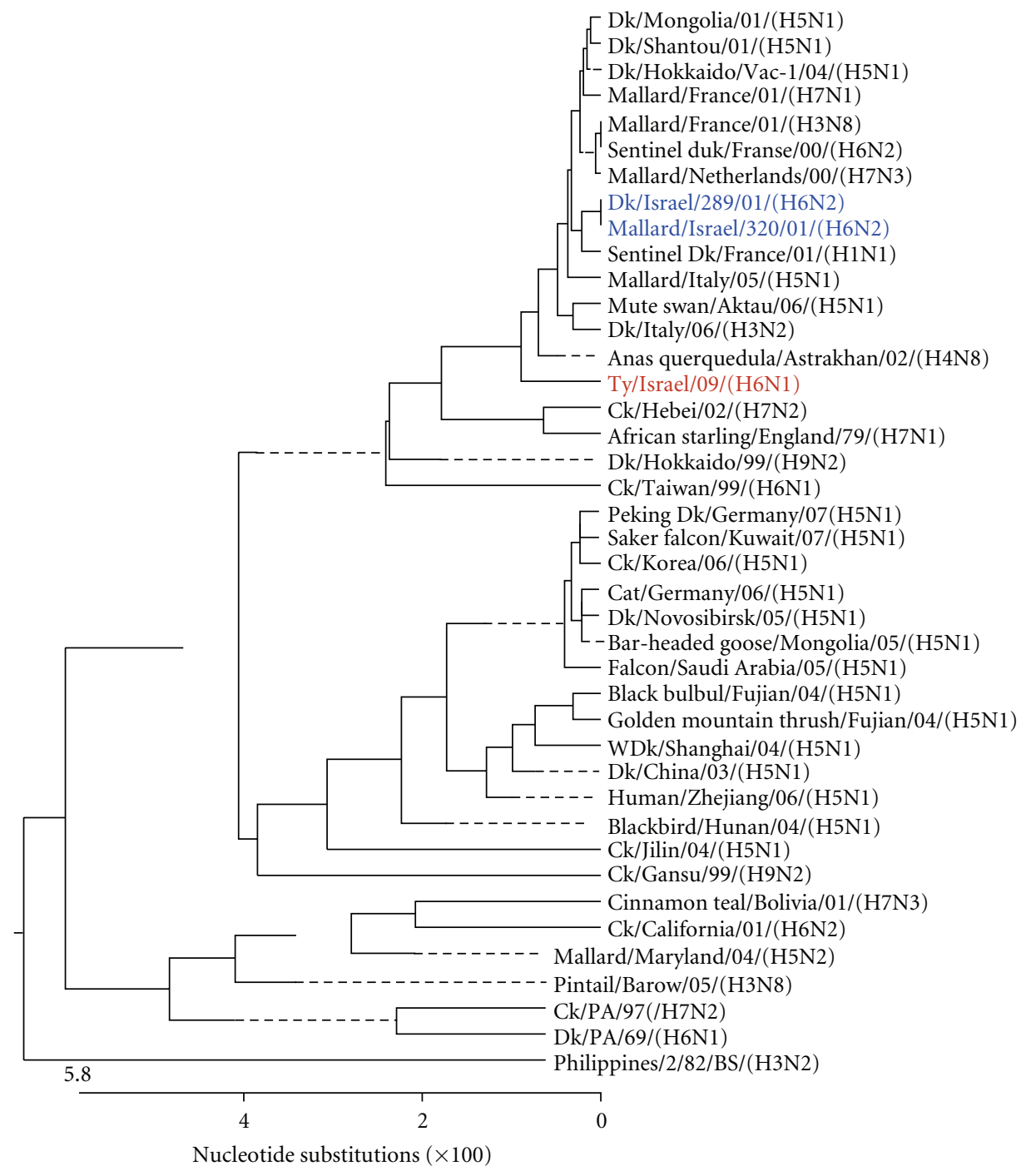

FIGURE 4: Phylogenetic tree of the M gene.

PCR. A/turkey/Israel/09 (H6N1) was characterized as low pathogenic avian influenza virus (LPAI) with an IVPI of 0.00. Infection in the chickens used in the IVPI assay was confirmed by the HI test.

3.3. Genetic Characterization of the Gene Cleavage Site. The amino acid sequence of the $\mathrm{H}$ gene cleavage site was examined to support the virulence determination of the A/turkey/Israel/09/(H6N1) isolate. The amino acid sequence at the cleavage site was PQIETR* GLF, indicating that the isolate was of low pathogenicity, since it did not contain multiple basic amino acids, characteristic of HPAIVs. Most LPAIVs have a single arginine at the cleavage site, whereas HPAIVs usually exhibit a multibasic amino acid motif ( $\mathrm{R}$ and K) flanking the cleavage site $[22,23]$.

3.4. Phylogenetic Analyses of the A/Turkey/Israel/09/(H6N1) Isolate Genes. The genome of influenza A viruses consists of eight unique segments of single-stranded RNA, which are of negative polarity (i.e., complementary to the mRNA sense) [5]. The 8 gene segments of the A/turkey/Israel/09 (H6N1) isolate were sequenced. The nucleotide sequences obtained in the present study were compared to those of AIVs from the GeneBank (Figures 1-8).

Figure 1 shows the phylogenetic tree of the complete $\mathrm{H}$ gene, subtype H6, of representative recent AIV H6 isolates reported worldwide, including the previous two Israeli H6 isolates, which were not reported to the GeneBank. The H genes examined formed two phylogenetic clades. It seems that the $\mathrm{H}$ gene of the present isolate, A/turkey/Israel/09 (H6N1), differed from the $\mathrm{H}$ genes of the two previous Israeli isolates, as they belonged to different clades, although the differences in the nucleotide content were about 3.7-3.8\%. It is notable that the H6 AIV, that shaped the clade to which the present isolate belonged, originated from waterbirds.

Figure 2 shows the phylogenetic tree of the $\mathrm{N}$ gene of N1 subtypes, based on the analysis of nucleotides 


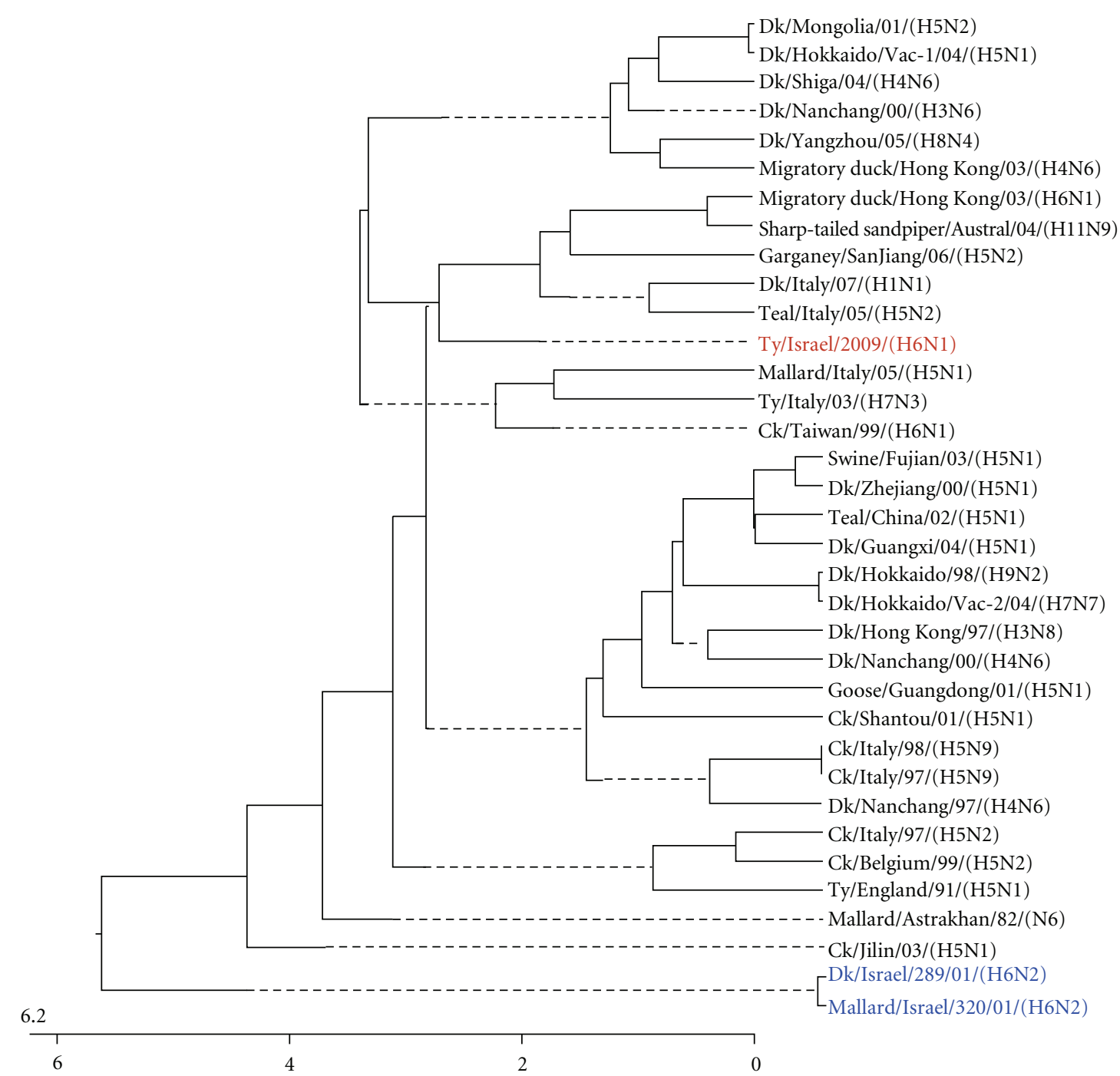

Nucleotide substitutions $(\times 100)$

FIGURE 5: Phylogenetic tree of the NP gene.

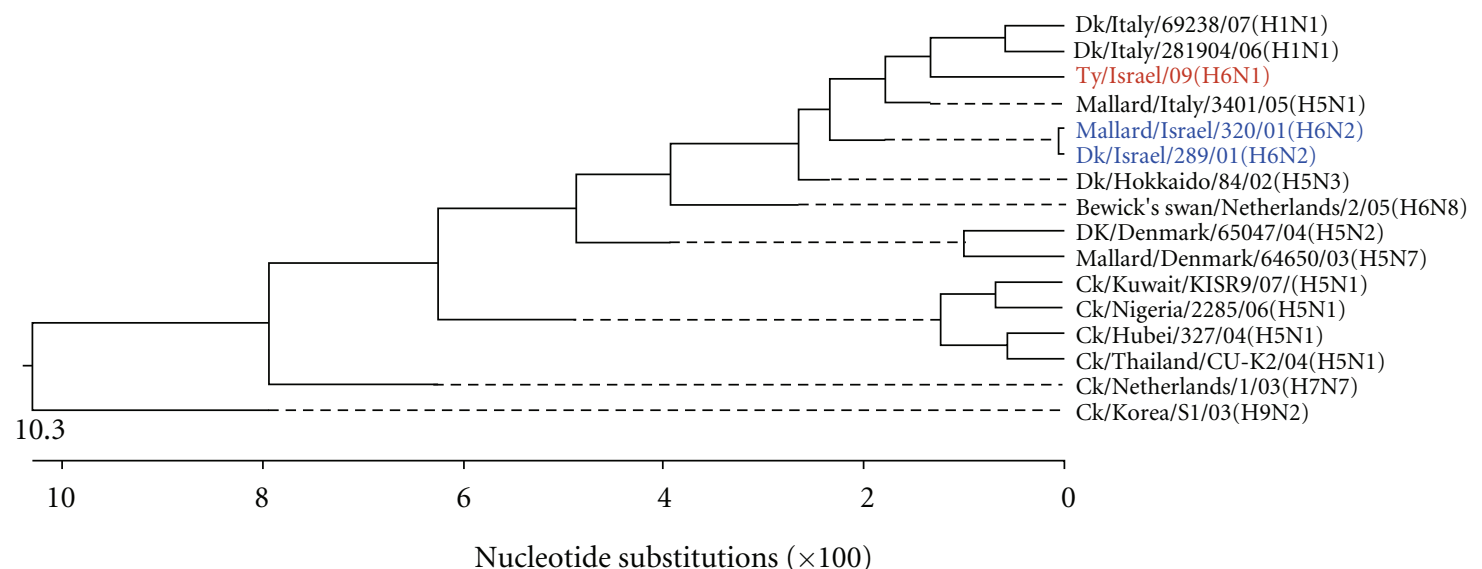

Figure 6: Phylogenetic tree of the PA gene. 


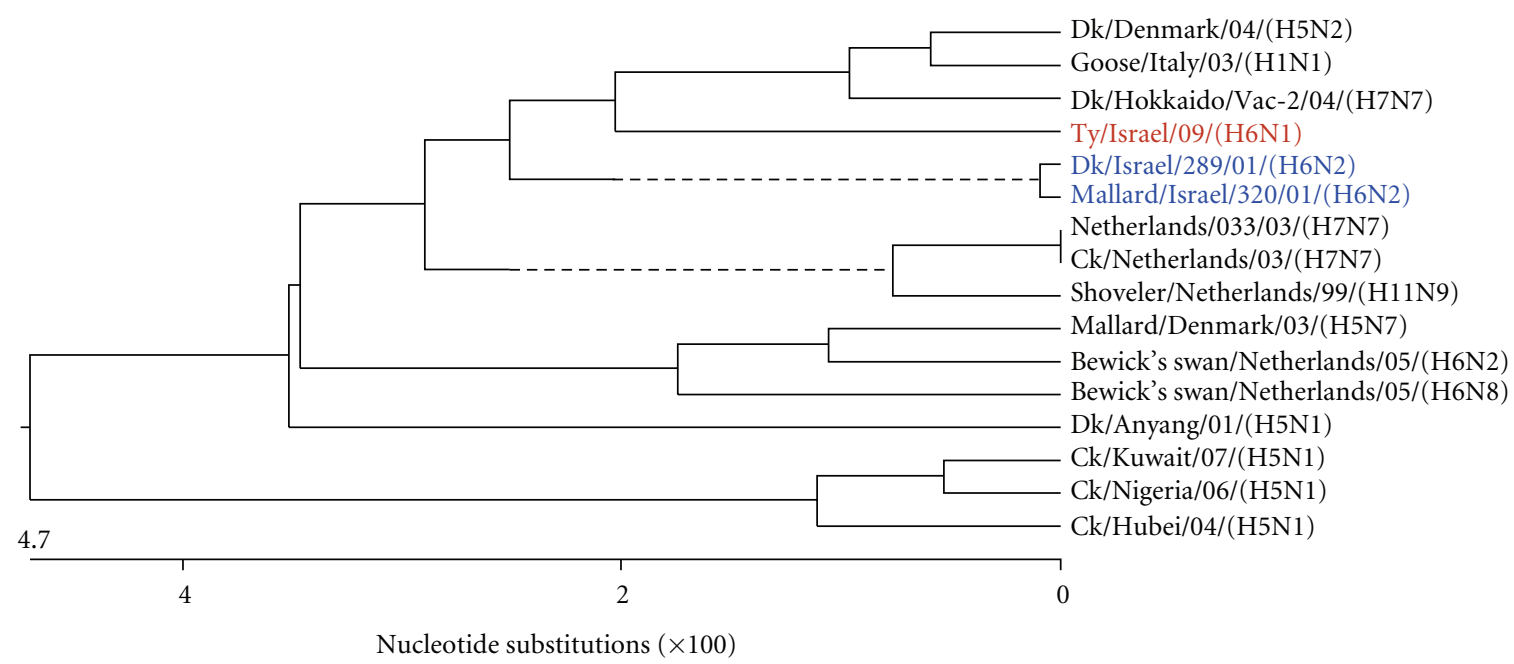

FIgURE 7: Phylogenetic tree of the PB1 gene.

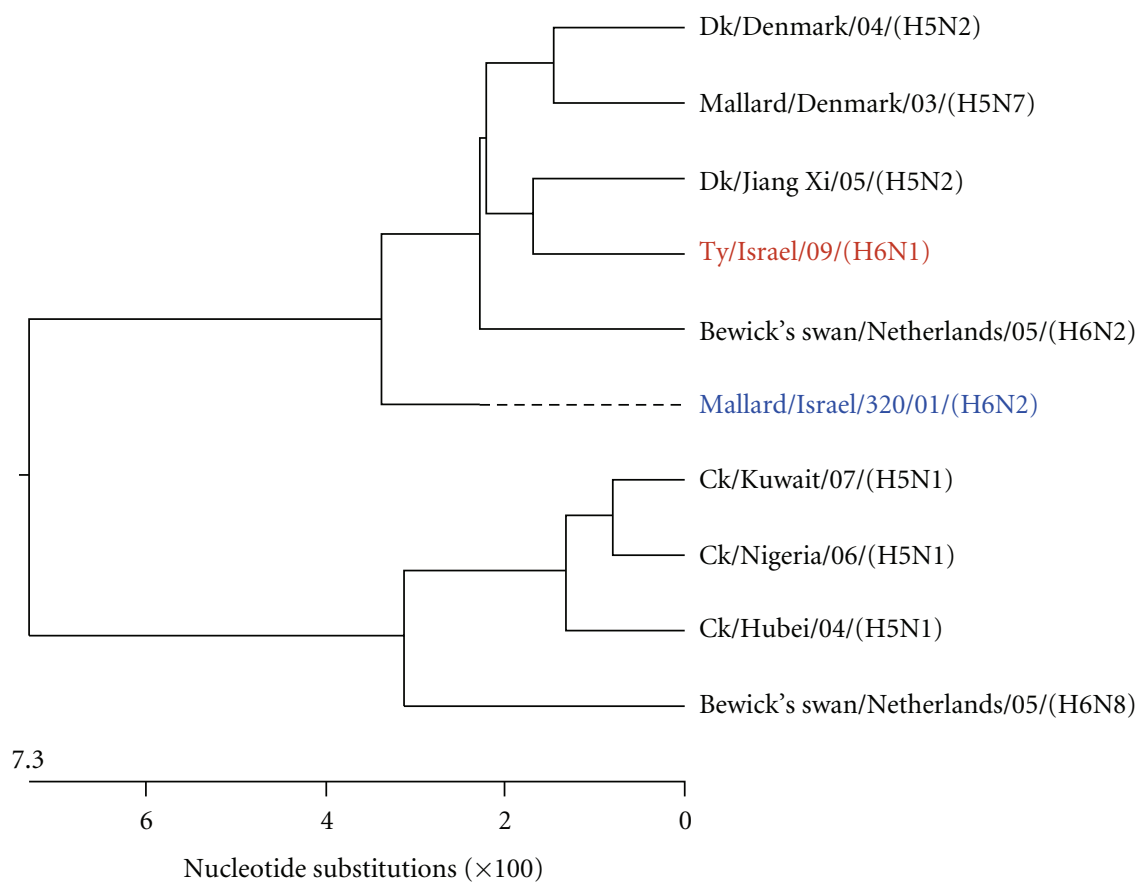

FIgURe 8: Phylogenetic tree of the PB2 gene.

204 to 1149 . The analysis includes representative AIV N1 genes compared on the respective gene fragment. While the compared sequences differed up to $31 \%$, the present isolate, A/turkey/Israel/09 (H6N1), was closest to the N1 from A/mute swan/Aktau/06 (H5N1) and A/swan/Mangystau/06 (H5N1). It is notable to mention that the Hong Kong avian A/teal/Hong Kong/W312/97 (H6N1) and the human influenza virus A/Hong Kong/156/97 (H5N1) showed a very high nucleotide homology in the 6 AIV internal genes, and especially in the N1 gene sequence $[14,24]$. That similarity might indicate a common precursor and that the present virus could become a potential source of novel pathogenic AIV strains.
Figures 3, 4, 5, 6, 7, and 8 show the phylogenetic comparison of the A/turkey/Israel/09 (H6N1) isolate complete internal genes, NS, M, NP, PA, PB1 and PB2, respectively, to genes of representative AIVs. The main feature revealed from these phylogenetic trees was the close similarity between the former two H6N2 AIV isolates, A/duck/Israel/289/01 and $\mathrm{A} /$ mallard/Israel/320/01, as compared to the phylogenetic divergence of the present H6N1 isolate, A/turkey/Israel/09. The phylogenetic distances between the 2009 H6N1 isolate and the two previous $\mathrm{H} 6 \mathrm{~N} 2$ isolates were calculated. While the two previously described H6 isolates, A/duck/Israel/289/01 (H6N2) and A/mallard/Israel/320/01 (H6N2), were identical in their NS, M, NP, PA, PB1, and PB2 
genes, the A/turkey/Israel/09 (H6N1) isolate differed from the former two isolates by $3 \%, 2.3 \%, 6 \%, 2.5 \%, 3.6 \%$, and $5 \%$, respectively.

In conclusion, the present paper describes a third $\mathrm{H} 6$ AIV isolate (H6N1) in Israel, which unlike the two previous H6N2 isolates that were obtained from ducks and mallard, was now detected in turkeys. This H6N1 LPAIV was shown to possess a low-pathogenic amino acid sequence at the cleavage site and had a low IVPI. Phylogenetic analysis of all genes suggested a different origin for the virus. A/turkey/Israel/09 (H6N1) was not highly transmissible among commercial flocks. That phenomenon was supported by two observations; (a) the absence of clinically-affected cases in adjacent poultry houses and (b) the detection of only three cases of AIV H6 in Israel.

\section{References}

[1] I. Capua and D. J. Alexander, "The challenge of avian influenza to the veterinary community," Avian Pathology, vol. 35, no. 3, pp. 189-205, 2006.

[2] P. F. Wright and R. G. Webster, "Ortomyxoviruses," in Fields, Virology, D. Knipe and P. Howley, Eds., vol. 4, pp. 1533-1539, Lippincott, Williams \& Wilkins, Philadelphia, Pa, USA, 2001.

[3] A. H. Reid, J. K. Taubenberger, and T. G. Fanning, "Evidence of an absence: the genetic origins of the 1918 pandemic influenza virus," Nature Reviews Microbiology, vol. 2, no. 11, pp. 909 914, 2004.

[4] J. K. Taubenberger, A. H. Reid, R. M. Lourens, R. Wang, G. Jin, and T. G. Fanning, "Characterization of the 1918 influenza virus polymerase genes," Nature, vol. 437, no. 7060, pp. 889893, 2005.

[5] R. G. Webster, W. J. Bean, O. T. Gorman, T. M. Chambers, and Y. Kawaoka, "Evolution and ecology of influenza A viruses," Microbiological Reviews, vol. 56, no. 1, pp. 152-179, 1992.

[6] C. L. Cheung, D. Vijaykrishna, G. J. D. Smith et al., "Establishment of influenza A virus (H6N1) in minor poultry species in southern China," Journal of Virology, vol. 81, no. 19, pp. 10402-10412, 2007.

[7] K. F. Shortridge, "Pandemic influenza: a zoonosis?" Seminars in Respiratory Infections, vol. 7, no. 1, pp. 11-25, 1992.

[8] V. J. Munster, C. Baas, P. Lexmond et al., "Spatial, temporal, and species variation in prevalence of influenza A viruses in wild migratory birds." PLoS Pathogens, vol. 3, no. 5, p. e61, 2007.

[9] E. Spackman, D. E. Stallknecht, R. D. Slemons et al., "Phylogenetic analyses of type A influenza genes in natural reservoir species in North America reveals genetic variation," Virus Research, vol. 114, no. 1-2, pp. 89-100, 2005.

[10] M. W. Jackwood, D. L. Suarez, D. Hilt et al., "Biologic characterization of chicken-derived H6N2 low pathogenic avian influenza viruses in chickens and ducks," Avian diseases, vol. 54, no. 1, pp. 120-125, 2010.

[11] C. Abolnik, S. Bisschop, T. Gerdes, A. Olivier, and R. Horner, "Outbreaks of avian influenza H6N2 viruses in chickens arose by a reassortment of H6N8 and H9N2 ostrich viruses," Virus Genes, vol. 34, no. 1, pp. 37-45, 2007.

[12] C. W. Wang and C. H. Wang, "Experimental selection of virus derivatives with variations in virulence from a single lowpathogenicity $\mathrm{H} 6 \mathrm{~N} 1$ avian influenza virus field isolate," Avian Diseases, vol. 47, no. 4, pp. 1416-1422, 2003.
[13] P. R. Woolcock, D. L. Suarez, and D. Kuney, "Lowpathogenicity avian influenza virus (H6N2) in chickens in California, 2000-02," Avian Diseases, vol. 47, pp. 872-881, 2003.

[14] E. Hoffmann, J. Stech, I. Leneva et al., "Characterization of the influenza A virus gene pool in avian species in southern China: was $\mathrm{H} 6 \mathrm{~N} 1 \mathrm{a}$ derivative or a precursor of $\mathrm{H} 5 \mathrm{~N} 1$ ?" Journal of Virology, vol. 74, no. 14, pp. 6309-6315, 2000.

[15] N. Golender, A. Panshin, C. Banet-Noach et al., "Genetic characterization of avian influenza viruses isolated in Israel during 2000-2006," Virus Genes, vol. 37, no. 3, pp. 289-297, 2008.

[16] S. Perk, N. Golender, C. Banet-Noach et al., "Phylogenetic analysis of hemagglutinin, neuroaminidase and nucleoprotein genes of H9N2 avian influenza viruses isolated in Israel during the 2000-2005 epizootic," Comparative Immunology, Microbiology and Infectious Diseases, vol. 32, pp. 221-238, 2009.

[17] D. E. Swayne, D. A. Senne, and C. W. Beard, "Influenza," in Isolation and Identification of Avian Pathogens, D. E. Swayne, J. R. Glisson, M. W. Jackwood, J. E. Pearson, and W. M. Read, Eds., pp. 150-155, American Association of Avian Pathologists, Kennett Square, Pa, USA, 4th edition, 1998.

[18] M. S. Lee, P. C. Chang, J. H. Shien, M. C. Cheng, and H. K. Shieh, "Identification and subtyping of avian influenza viruses by reverse transcription-PCR," Journal of Virological Methods, vol. 97, no. 1-2, pp. 13-22, 2001.

[19] M. J. Slomka, V. J. Coward, J. Banks et al., "Identification of sensitive and specific avian influenza polymerase chain reaction methods through blind ring trials organized in the European Union," Avian Diseases, vol. 51, no. 1, pp. 227-234, 2007.

[20] K. E. Wright, G. A. R. Wilson, D. Novosad, C. Dimock, D. Tan, and J. M. Weber, "Typing and subtyping of influenza viruses in clinical samples by PCR," Journal of Clinical Microbiology, vol. 33, no. 5, pp. 1180-1184, 1995.

[21] Office International des Epizooties, World organization for Animal Health, "Highly pathogenic avian influenza (fowl plague)," in Manual of Standards for Diagnostic Tests and Vaccines, pp. 212-220, Office International des Epizooties, Paris, France, 2001.

[22] H. D. Klenk, M. N. Matrosovich, and J. Stech, "Cleavage activation of the influenza virus hemagglutinin and its role in pathogenesis," in Avian Influenza, vol. 27 of Monographs in Virology, pp. 156-167, Wiley-Blackwell, Marburg, Germany, 2008.

[23] D. A. Steinhauer, "Role of hemagglutinin cleavage for the pathogenicity of influenza virus," Virology, vol. 258, no. 1, pp. 1-20, 1999.

[24] P. S. Chin, E. Hoffmann, R. Webby et al., "Molecular evolution of H6 influenza viruses from poultry in southeastern China: prevalence of $\mathrm{H} 6 \mathrm{~N} 1$ influenza viruses possessing seven A/Hong Kong/156/97 (H5N1)-like genes in poultry," Journal of Virology, vol. 76, no. 2, pp. 507-516, 2002. 


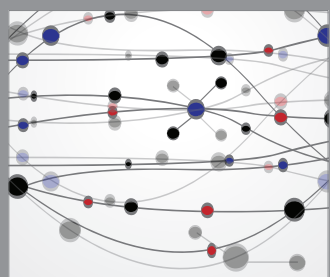

The Scientific World Journal
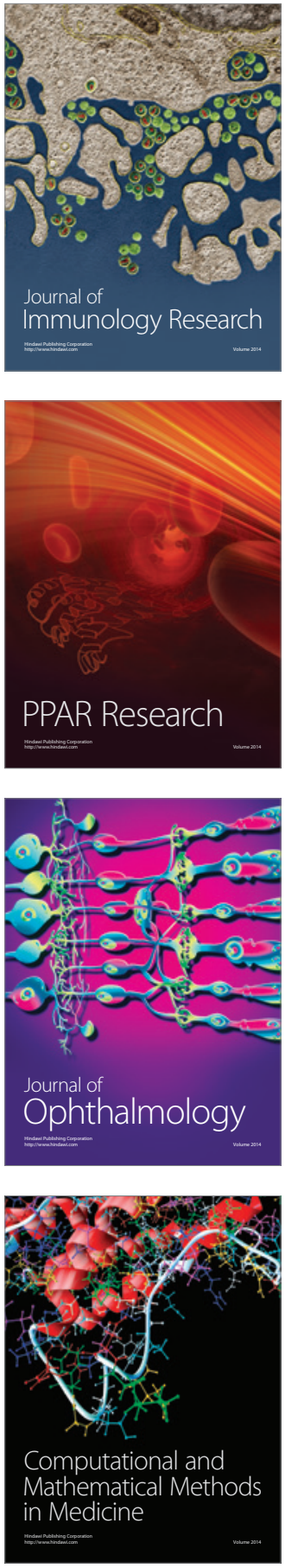

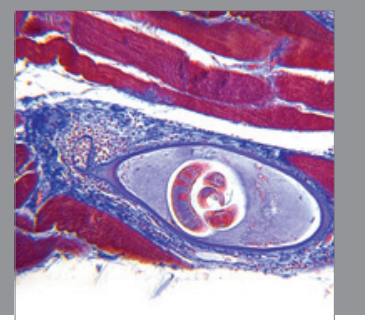

Gastroenterology

Research and Practice
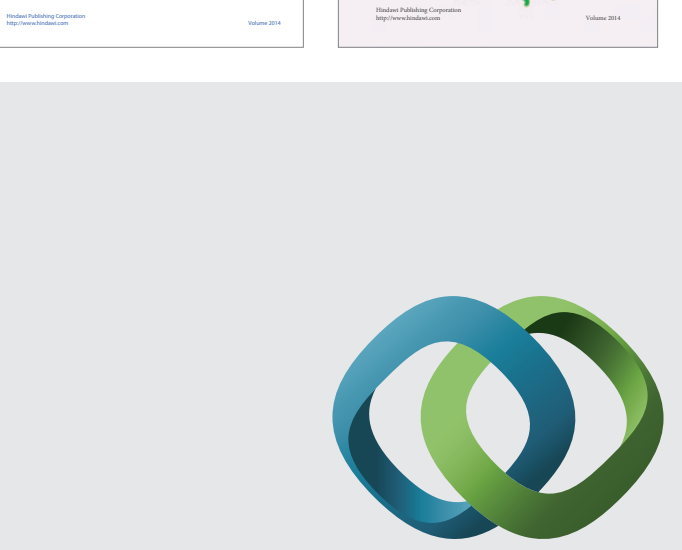

\section{Hindawi}

Submit your manuscripts at

http://www.hindawi.com
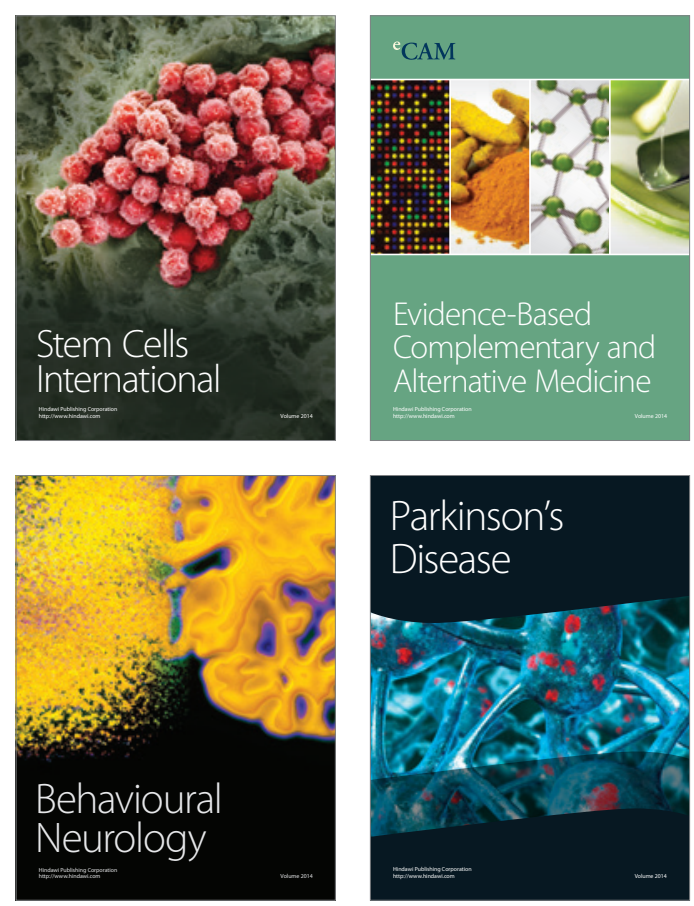

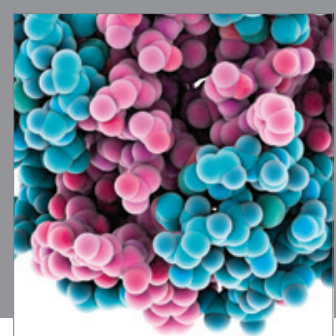

Journal of
Diabetes Research

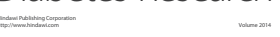

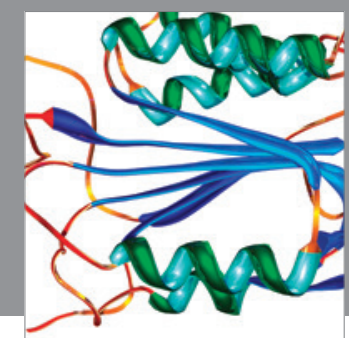

Disease Markers
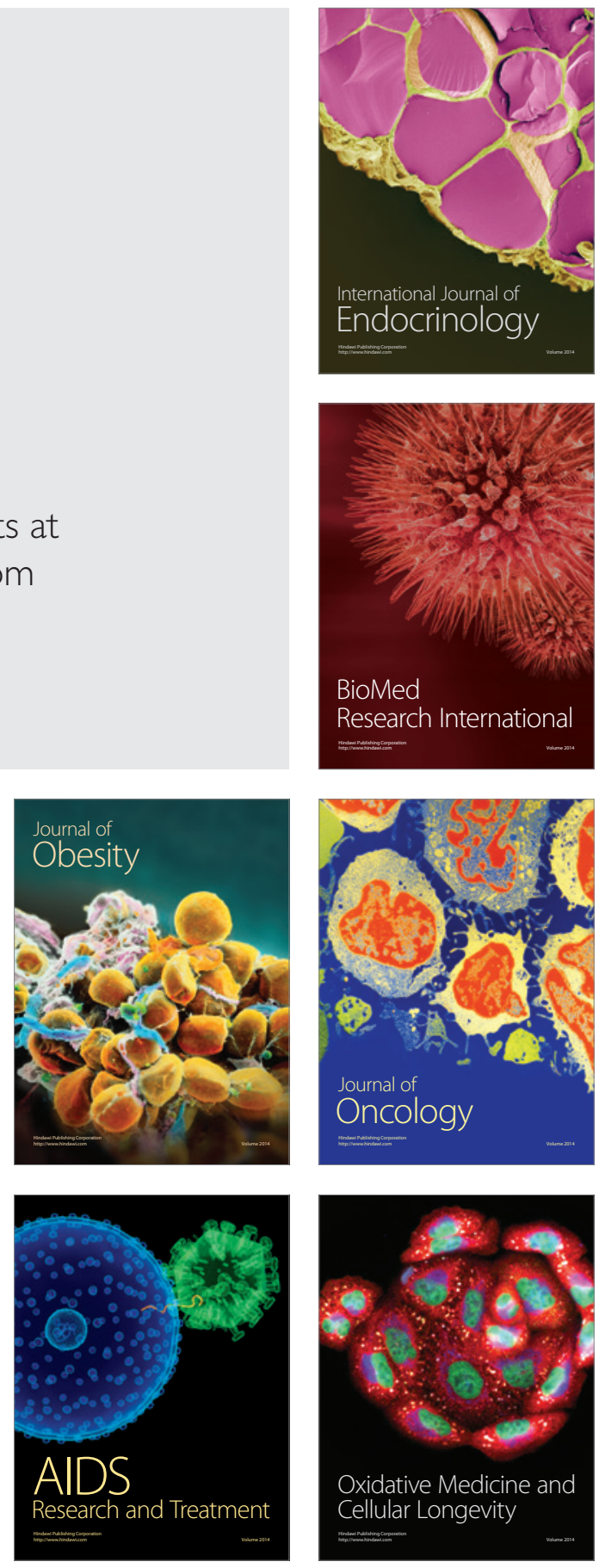